\title{
ACCUMULATED REFLECTANCE TECHNIQUE FOR SAMPLING DELIMITATION IN THE RIACHO FUNDO CREEK, LAGO PARANOÁ-DF, FROM PLANETSCOPE IMAGES
}

\author{
C. S. Marinho', V. Sacramento ${ }^{1}$, M. R. Cangiano ${ }^{1}$, R. E. Cicerelli ${ }^{1}$, T. Almeida ${ }^{1}$
}

\begin{abstract}
${ }^{1}$ Universidade de Brasília, Instituto de Geociências, Campus Universitário Darcy Ribeiro, Asa Norte, CEP 70910-900 Brasília, DF, Brasil. E-mails: csm.cinthya@gmail.com, sacramento.unb@gmail.com, marinarcangiano@gmail.com, rejaneig@unb.br, tati_almeida@unb.br
\end{abstract}

KEY WORDS: Accumulated Reflectance, Sampling Delimitation, Unsupervised Classification, PlanetScope Products, Inland Waters, Complex Waters, Optically Active Components (OAC)

\begin{abstract}
:
The delimitation of sampling points is an important step to avoid unnecessary costs in water collection process and laboratory analysis. Based on the accumulated reflectance of PlanetScope imagens, it was possible to verify areas of greater spectral variability related to the presence of Optically Active Components (OAC). In order to do that, the accumulated reflectance method was used, based on multitemporal images. For that, three PlanetScope Ortho Scene Products were tested: Atmospheric Corrected for Surface Reflectance (SR), Digital Number (DN), and Top of Atmosphere Reflectance (TOA) images. SR and DN products had similar outcome, while DN product was not ideal for the purpose of this article. Even though SR and DN products were able to delimitate sampling points, they may have radiometric issues, mainly because of their near infrared values.
\end{abstract}

\section{INTRODUCTION}

One of the advantages of remote sensing analysis in aquatic environments is the ability to verify the spacial and temporal variability of water composition, thus allowing the investigation of the origin and displacement of specific optically active substances, dissolved or in suspension in the water, which are suspended sediments, photosynthesizes pigments, dissolved organic matter e water molecules (CASTRO, PEREIRA \& BARROS, 2016; RUDORFF, 2006; JENSEN, 2011).

Optically Active Components (OAC) interact in two ways with electromagnetic radiation (REM) by scattering and absorbing such that the water surface represents the link between the physical, chemical and biological properties of the aquatic system and the energy captured by a positioned sensor above the body of water. The water surface is associated with primary productivity, it depends on the availability of light, the geological substrate and the land use and cover characteristics in the region where the water body is inserted (NOVO et al, 2019).

Thus, the spectral conduct of aquatic systems depends on the composition of the body of water with respect to OAC concentrations, the geometric properties of the light field incident on the water and the aquatic system itself, and the state of the surface of the system. aquatic. They are also dependent on the acquisition geometry of remote sensing reflectance spectrums, which demonstrates their potentiality in estimating OAC concentrations to characterize water bodies (NOVO et al, 2019).
Spectral bands between 400 and 900 are ideal for passive sensors to analyze aquatic environment in what is called Water Colour Remote Sensing. Even though identifying and extracting radiation from water column is a challenge due to atmospheric interference, sunglint effect, and interaction with other constituents, for example (NOVO et al, 2019).

Each OAC has specific optical absorption and scattering properties of radiation. In pure water, absorption is very low in the blue and green regions, being significant only from $550 \mathrm{~nm}$, with high absorption values at the end of red and near infrared. For suspended sediments, composed of phytoplankton and Non Algal Particles (NAP), the higher the concentration, the reflectance peak goes to the right. NAP do not absorb much light, but scatters it intensely. Most of absorption spectrums for NAP have higher values in the ultraviolet and blue spectral region, decreasing exponentially towards the largest wavelengths, and reaching very low or missing values at the end of red and beginning of near infrared. The presence of phytoplankton is generally indicated by chlorophyll- $a$ (Chl- $a)$ concentrations. It has strong absorption bands in blue $(\sim 430$ $\mathrm{nm})$ and red $(\sim 665 \mathrm{~nm})$ and maximum reflectance at $\sim 550 \mathrm{~nm}$ and a reflectance peak around 690-700 nm. For Colored Dissolved Organic Matter (CDOM), the absorption coefficient at $440 \mathrm{~nm}$ is commonly used as an indicator of its concentration in natural waters (NOVO et al, 2019; JENSEN, 2011).

Remote Sensing is being largely used to monitor water quality, with estimation of OAC (Kirk, 1994; Astuti et al., 2018; Dörnhöfer K. e Oppelt N., 2016; Machado e Baptista 2016). However, there are few studies in aquatic environments with Planet imagery, the newest generation of satellite images of 
high spatial resolution $(3 \mathrm{~m})$ and almost daily temporal resolution, capable of recording an area of 150 million $\mathrm{km}^{2}$ per day. These images have a spatial resolution of 3 meters and have the following spectral bands: B1: blue $(455-515 \mathrm{~nm})$; B2: green $(500-590 \mathrm{~nm})$; B3: red $(590-670 \mathrm{~nm})$, and B4: near infrared (NIR) $(780-860 \mathrm{~nm})$.

Many urban lakes have eutrophication problems, which is the case of a Paranoá Lake creek called Riacho Fundo, which constitutes the region of interest for this study. That area is located in the Distrito Federal region, on the context of the Lake Paranoá watershed, which was initially created to mitigate the low humidity on the dry season and as an entertainment for it population. However, as it is near an urban area, the lake now receives fuzzy and punctual sewer, from CAESB (Companhia de Água e Esgoto de Brasília), and potentially from clandestine residential sources. This results in an increase of nutrients, especially nitrogen and phosphorus of the water body (BAPTISTA e NETO, 2008). After the hydric crisis that happened in Distrito Federal in 2017 and studies that showed limitations regarding public supply by Descoberto River, in Santa Maria and the Torto reservoir, the water company itself created a water catchment system in the Paranoá Lake.

Some techniques can be utilized to help and monitor of water quality in urban lakes. Hermuche \& Sano (2010), Grande et al. (2016) e Almeida et al (2017) have shown the use of multi temporal accumulated images to classify and identify both for vegetation phyto physiognomy, and for water composition, the results were positive, due to seasonal variability of the region.

Based on these concepts, paper was to delimitate areas of greater variability in relation to Optically Active Components (OAC), in order to better choose water sampling points.

\section{MATERIAL AND METHODS}

\subsection{Study Area}

Paranoá's lake watershed is located entirely in central region of Distrito Federal (DF) (figure 1), at an elevation approximately of 1000 meters. Its area corresponds to $18 \%$ of DF, approximately $1.304,07 \mathrm{~km}^{2}$. The region climate is compound by two definite seasons: hot and rainy summer, and dry and cold winter (Ferrante et al., 2001). Among its main creeks are: Ribeirões Bananal e do Torto, ao Norte; e Córrego Cabeça de Veado, Ribeirão do Gama e Riacho Fundo, ao Sul (Codeplan, 1994).

The Riacho Fundo creek is considered one of the most polluted in the basin due to factors such as the accelerated urbanization process, the discharge of effluents into the drainage pattern and the discharge of effluents from sewage treatment plant (ETE Sul) (Caesb, 2018a). Therefore, it was classified as restricted and unsuitable for bathing, according to Paranoá's Lake Bathing Map (Caesb, 2018b) and it was the region of choice for this study.

\subsection{Selected Images}

The applied methods to this research were based on eight "PlanetScope Ortho Scene Product, Surface Reflectance
Product of (Analytic_SR)" images, which are divided in 3 levels processing, orthorectified and atmospheric corrected for surface reflectance (SR), furthermore two lower level products of pre-processing were used. The digital number file (DN), which does not yet include conversion to radiance or reflectance values, as well as not necessarily having DN compatibility between the spectral bands, making the spectral characterization of objects difficult. The last product is the Top of atmosphere reflectance (TOA), which is the DN product converted to reflectance values, with no atmospheric correction yet. The images were chosen to contemplate the four seasons of the year, with two images per season and presenting a maximum of $5 \%$ of cloud cover (NV). The following dates were chosen: summer $(03 / 01 / 2019,1 \% \mathrm{NV} ; 17 / 12 / 2018$, $1 \% \mathrm{NV})$, autumn $(13 / 03 / 2019,5 \% \mathrm{NV} ; 12 / 03 / 2019,4 \% \mathrm{NV})$, winter $(16 / 06 / 2018,0 \% \mathrm{NV} ; 16 / 07 / 2018,0 \% \mathrm{NV})$ and spring (12/09/2018, 0\% NV; 14/10/2018, 0\% NV).

\subsection{Accumulated Reflectance Technique}

The Accumulated Reflectance Technique was chosen to evaluate the spectral responses of the water body, in order to suppress the seasonal trends that occur in Lake Paranoá. This technique was performed from the accumulated digital values of multitemporal images, which consisted of a band arithmetic sum of the eight images by means of ENVI software, version 5.5. For this purpose, the bands of the eight images were linked in a single product, for the sum of bands, generating four products referring to the four spectral bands of the eight Planet images. These four products were merged into one final image containing the four spectral bands of the eight summed images. This final product was used in the following steps.

\subsection{Accumulated Reflectance Product Classification}

From the final product, the unsupervised classification method - ISODATA was applied through the ENVI software for class separation according to spectral variability. The ISODATA algorithm allows grouping of data about a set region, which are characterized by their statics attributes of mean, covariance matrix and area (SPRING, 2017). The following classification parameters were applied: number of classes -3 and 10; Smooth Kernel Size: 17, for both class numbers; Aggregate Minimum Size: 17, for both class numbers. The classification was made only after the final image was cropped according to the study area, so that only the water body pixels interfered with the classification. During this process, it was also decided to generate a vector file with the created classes. The collection points were distributed from the created classes, with three points per class, randomly.

For class representation, the measurement mode defined by Bertin (1967) was used as categorical selective relation in ArcGis software, version 10.6. However, the classes order was defined before that, based on the standard deviation of the classes in relation to the green band of the final product of accumulated bands in the ENVI software. Thus, it was possible to define the classes with the highest variation and this order was manually placed in ArcGis before the selection of the warm and cold color ramp, being the warmest colors for the 
classes with the highest variation and the colder colors for the classes with slight variation, as can be seen in figure 1 .

After that, a sample point distribution was made, based on a stratified, non-aligned, random technique, in which two points per class was defined.

\section{RESULTS AND DISCUSSION}

Table 1 shows standard deviation values for the accumulated reflectance of the green band of the PlanetScope product generated with the Accumulated Reflectance Technique. The bigger the standard deviation, the bigger the spectral variability through time and, consequently, the bigger the need of monitoring these areas (CASTRO, PEREIRA E BARROS, 2016). Thus, the table below was ordered from higher to lower spectral variability of the classes.

\begin{tabular}{|c|c|c|}
\hline Classes & SD_B2* & Area $\left(\mathrm{m}^{2}\right)$ \\
\hline Class10 & 380,353731 & 14,832 \\
\hline Class8 & 310,960769 & 17,631 \\
\hline Class7 & 214,368117 & 9,603 \\
\hline Class6 & 167,113808 & 46,242 \\
\hline Class3 & 149,374757 & 111,681 \\
\hline Class5 & 122,473212 & 66,852 \\
\hline Class4 & 95,82321 & 108,585 \\
\hline
\end{tabular}

Values of standard deviation of the green band were chosen for ordering the classes, since this band is expected to have the higher reflectance response to phytoplankton in water for this sensor.

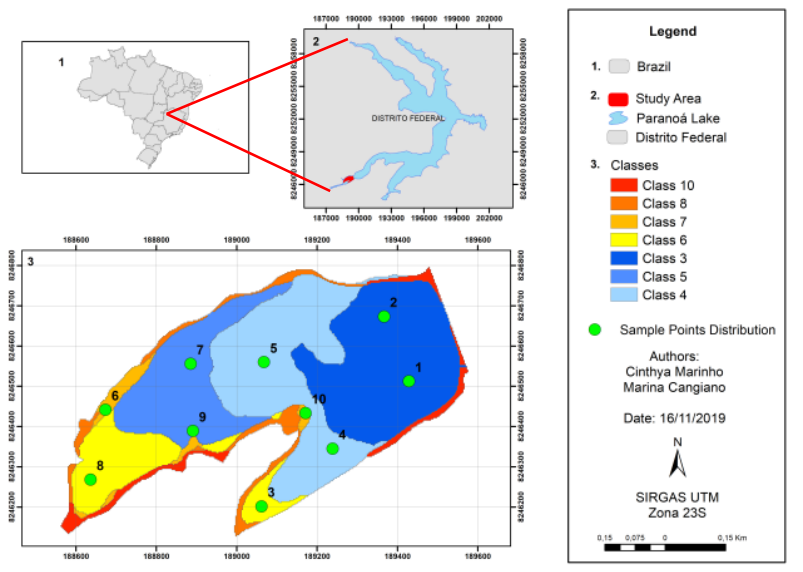

Figura 1: Classification and Sampling Delimitation Map

Classes 10 and 8 (Figure 1) were not considered, because the spectral response they show is probably due to the reflection of the water body bottom, in which the response has low intensity and its spectral variation is on account of both the water body and the bottom of the lake (NOVO et al, 2019). Besides that, there might have a mixture with adjacent pixels, not related to the water body.

Three other classes were not a part of the point distribution (classes 2, 9 and 1), for they do not have any spectral variability after the band statistics process. Thereby, these classes are not a part of data visualization in ArcGIS (figure 1). Therefore, only classes 3 to 7 were taken into account for the point distribution, and the result consists of 10 sampling points, two per class.

Amongst the classes of interest, class 7 represents the bigger spectral variability. This is probably due to the fact that these areas are on the output of the Riacho Fundo creek. Class 6, immediately after class 7 in the standard deviation classification, corresponds to areas of influence of the Sewage Treatment Plant (ETE sul), and indirectly, of the Riacho Fundo creek. Additional studies are necessary to confirm these results and to better define the other classes. As it shows, PlanetScope products are promising for sampling delimitation.

Besides presented classification using the SR product, other were generated, in the same way, from two different Planet products (TOA and DN), for purposes of comparing them (figure 2).

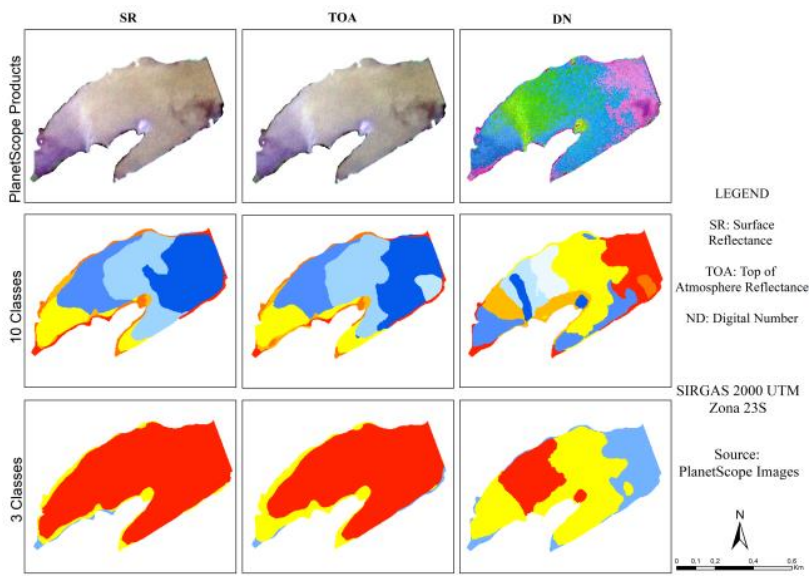

Figura 2: PlanetScope Accumulated Products (SR, TOA and DN) Classifications.

Line 1: Final products; line 2: Products divided in two classes; line 3: Products divided in 3 classes

For each of the three products (RS, TOA, DN), generated with accumulated reflectance, two classifications were made, generating both three and ten classes (Figure 2). For both RS and TOA, the classifications were similar, so it is possible to choose from any of them as for sampling delimitation. Thus, it was possible to observe that the 10 -class division made more sense, as the 3-class division basically put the entire area into 1 class. On the other hand, the DN product behaves erratically, resulting in classes that make no sense.

Although visually the ratings of RS, TOA products make sense, their reflectance values cannot be used as a parameter for indirect inference with water components. The near infrared values were higher than those of the other bands in all images, as well as in the sum of bands, as shown in charts 2 and 3, respectively. This pattern is not expected for any water component, so these images are likely to have radiometric problems. 


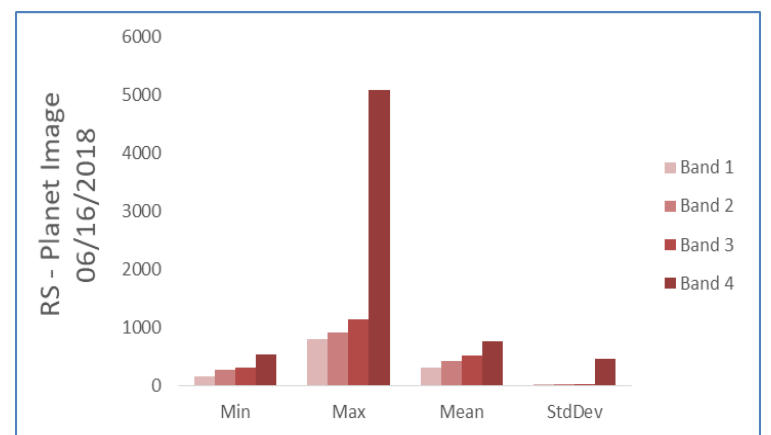

Gráfico 1: PlanetScope Image SR - 16/06/2018

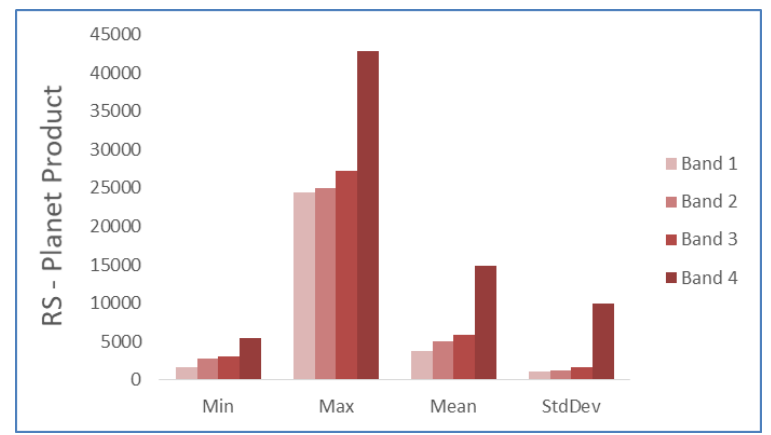

Gráfico 2: Planet Product SR (Sum of Bands)

\section{CONCLUSIONS}

4.1 The accumulated reflectance technique is capable of separating areas of greater spectral variability through time in water bodies, as for sampling delimitation;

4.2 Planet RS and TOA products have obtained similar results for water body classification, and both can be used for this purpose;

4.3 Planet ND product has had insufficient results for water body classification.

4.4 PlanetScope images may have radiometric issues, based on the near infrared values in all of them. Those values are higher than expected for any water optical component.

\section{ACKNOWLEDGEMENTS}

The authors would like to gratefully acknowledge the support of the following agencies: CNPq (Conselho Nacional de Desenvolvimento Científico e Tecnológico), CAPES(Coordenação de Aperfeiçoamento de Pessoal de Nível Superior)

\section{REFERENCES}

Almeida, T.; Cicerelli, R. E.; et al. 2018. Delineamento amostral no monitoramento de reservatório de uso múltiplo utilizando valores digitais acumulados em imagens
OLI/Landsat 8. Sustainability, agriculture, food and environmental research, 8 (3), 28-35.

Astuti, I. S. et al. 2018. Spatio-temporal dynamics of inherent optical properties in oligotrophic northern Gulf of Mexico estuaries. Continental Shelf Research, ISSN: 0278-4343, Vol: 166, Page: 92-107. DOI: 10.1016/j.csr.2018.06.016.

Baptista, G. M.; Neto, M. D. A. 2008. O processo de eutrofização artificial no lago Paranoá, Brasília, DF, GEONOMOS, 2 (2), 31-39.

Bertin, J. 1986 [1977]. A neográfica e o tratamento gráfico da informação. Curitiba: UFPR.

Blaschke, T. 2010. Object based image analysis for remote sensing. ISPRS Journal of Photogrammetry and Remote Sensing, 65, 2-16.

CAESB - Companhia de Saneamento Ambiental do Distrito Federal. (2018a). Estações de Tratamento de Esgoto. <http://atlascaesb.maps.arcgis.com/apps/MapJournal/index.htm 1?appid=9babae05a8a1444180cdf3df83f67fb7 > Last date in: 02 June 2019.

CAESB - Companhia de Saneamento Ambiental do Distrito Federal. (2018b). Mapa de Balneabilidade do Lago Paranoá. $<$ https://atlas.caesb.df.gov.br/MapaBalneabilidade/>. Last date in: 02 June 2019.

Castro, P. H. M; Pereira, A. C. F and Barros, M. V. F 2016. Modelagem Amostral para o Monitoramento de Componentes Opticamente Ativos no rio Tibagi/PR, utilizando Imagens Landsat 8/OLI. Revista Brasileira de Cartografia, n. 69.

CODEPLAN - Companhia de Desenvolvimento e Planejamento. 1994. Mapa do Distrito Federal e Mapa das Unidades Hidrográficas do DF. Brasília, DF.

Davis, C., Câmera, G. e Monteiro, A.M. Introdução à Geoinformática.

<http://www.dpi.inpe.br/gilberto/livro/introd/index.html> Last date in: 20 April 2019.

Dörnhöfer, K; Oppelt, N. 2016. Remote sensing for lake research and monitoring - Recent advances. Ecological Indicators, ISSN: 1470-160X, Vol: 64, Page: 105-122. Department of Geography, Kiel University, Germany. DOI: 10.1016/j.ecolind.2015.12.009.

Ferrante J. E. T., Rancan L., Netto P. B. (2001). Meio Físico In: Fonseca, F. O. edição SEMARH (eds.). Olhares sobre o Lago Paranoá. Brasília Press. pp.: 4579.

Grande, T. O., Almeida T., e Cicerelli, R.E. 2017. Classificação orientada a objeto em associação às ferramentas reflectância acumulada e mineração de dados. Pesquisa Agropecuária Brasileira, 51 (12), 1983-1991.

Hermuche, P. M. \& Sano, E.E. 2012. Identificação da floresta estacional decidual no Vão do Paranã, estado de Goiás, a partir da análise da reflectância acumulada de imagens do sensor ETM+/Landsat-7. Revista Brasileira de Cartografia. 
IBGE, 2010. Censo 2010. 〈www. ibge. gov.br/censo2010> Last date in: 14 July 2016.

Jensen J. R. 2011. Sensoriamento remoto do ambiente: uma perspectiva em recursos terrestres. 2 ed. Tradução: José Carlos Neves Epiphanio (coordenador) ... [et al.] São José dos Campos, SP: Parêntese.

Kirk, J. T. 1994. Light and photosynthesis in aquatic ecosystems. Cambridge: Cambridge University Press.

Machado, M. T. de S. M.; Baptista, G. M. de M. 2016. Sensoriamento remoto como ferramenta de monitoramento da qualidade da água do Lago Paranoá (DF). Eng. Sanit. Ambient., Rio de Janeiro, v. 21, n. 2, p. 357-365, jun. 2016. DOI: 10.1590/S1413-41522016141970.

Neto, J.M.N. \& Moita, G.C. 1998. Uma introdução à análise exploratória de dados multivariados. Química Nova, 21(4):467-469.

Novo, E.M.L..M; Barbosa, C.C.F; e Lobo, F.L. 2019. Comportamento espectral dos ambientes aquáticos (Cap 7). Reflectância dos Materiais Terrestres - análise $e$ interpretação. Org: Meneses, Paulo Roberto; Almeida, Tati; Baptista, Gustavo Macedo de Mello. Ed. Oficina de Texto, 224-274, São Paulo.

Rudorff, C. M. 2006. Estudo da composição das águas da planície amazônica por meio de dados de reflectância do sensor Hyperion/eo-1 e de espectrorradiômetro de campo visando à compreensão da variação temporal dos seus constituintes opticamente ativos. Dissertação (Mestrado em Sensoriamento Remoto) Instituto Nacional de Pesquisas Espaciais - INPE, São José dos Campos, 138p.

SPRING, Manuais - Tutorial de Geoprocessamento: Classificação de Imagens. <http://www.dpi.inpe.br/spring/portugues/tutorial/classific.htm 1> Last date in: 21 May 2018. 